\title{
Occurrence of pathogenic and endophytic fungi and their influence on quality of medicinal plants applied in management of neurological diseases and mental disorders
}

\author{
KATARZYNA WIELGUSZ ${ }^{1}$, LIDIA IRZYKOWSKA ${ }^{2 *}$
}

${ }^{1}$ Institute of Natural Fibers and Medicinal Plants

Department of Breeding and Agriculture of Fibrous and Energetic Plants

Wojska Polskiego 71b

60-630 Poznań, Poland

${ }^{2}$ Poznan University of Life Sciences

Department of Phytopathology, Seed Science and Technology

Dąbrowskiego 159

60-594 Poznań, Poland

*corresponding author: phone: 4861848 79 27, fax: 486184879 99, e-mail: irzyk@up.poznan.pl

\section{Summary}

Due to increasing demand of medicinal plants (MPs), quality and safety more attention to the plant health should be paid. Among herb pathogens, especially fungi cause serious diseases in these plants decreasing yield and quality of herbal raw material. Some species, i.e. Fusarium sp., Alternaria sp., Penicillium sp. are known as mycotoxin producers. Paradoxically, self-treatment with herbal raw material can expose the patient to mycotoxin activity. In tissues of some MPs species, asymptomatically endophytic fungi residue. It is known that they are able to influence a biosynthesis of secondary metabolites in their host plant or produce biologically active compounds. Until recently these microorganisms have been neglected as a component of MPs, the reason why there have unexplored bioactivity and biodiversity. The paper presents an overview of herbal plants that are used in the treatment of nervous system diseases. Pathogenic fungi that infect these plants are described. It focused mainly on species producing harmful mycotoxins. The publication presents a list of these mycotoxins and a brief description of their effects on human health. The second part of this article provides information on the occurrence of endophytic fungi in herbal plants and their effects on human health. Coexistence of fungi and medicinal plants is not fully understood but can be crucial to ensure health and safety of patients with neurological diseases and mental disorders.

Key words: herbal medicines, phytotherapy, medicinal plant diseases, pathogenic fungi of plants, mycotoxins, endophytes, neurological diseases, mental disorders 


\section{INTRODUCTION}

Medicinal and aromatic plants (MPs) are important in the life of people worldwide [1-3]. Due to beneficial effects of medicinal plants on health and wellness they play a significant role in a social, cultural and ecological aspect of local communities providing people with medicines to maintain health and prevent or cure diseases [4]. In general, derived compounds of the secondary plant metabolism are responsible for the efficacy of medicinal plants. MPs utilization is present in the traditional medicine till today, since significant part of world population still relies on MPs in their medications $[5,6]$. The popularity of herbal medicines may be partially explained by the tendency of herbs to work slowly with minimal toxic side effects [7]. In some countries, the economic aspect is also important.

In $20^{\text {th }}$ century, a remarkable progress in medicine occurred that made most of the somatic diseases curable. However, medicinal options in neurology and psychiatry are still insufficient. Neither cure nor preventive care exists for major mental disorders, such as major depression, or i.e. for neurodevelopmental disorders represented by heterogeneous autistic spectrum disorders [8]. The World Health Organization [9] claimed that over one billion people worldwide suffer from neurological diseases or mental disorders [10]. Neurological diseases include epilepsy, dementias, migraine and multiple sclerosis. Mental disorders, on the other hand, i.e. anxiety, depression, schizophrenia are severe. As a consequence, they generate enormous costs of hospitalization, loss of working hours and early retirement [8]. Mental, neurological, and substance-addiction disorders affect every community and age group in all countries. Unfortunately, most of people affected (75\% in low-income countries) do not have access to the treatment they need [10].

Traditional medicine is used worldwide and it is of great economic importance in the $21^{\text {st }}$ century [11]. Recently, in Europe and USA some kind of the renaissance of MPs applications can be noted. They are used widely as a source of biologically active compounds with therapeutic properties. Medicinal plants are extensively applied to cure neurological and psychiatric problems. Stress and anxiety are a normal part of life, but anxiety disorders, affecting 40 million adults, are the most common mental disorder in Europe and USA [12, 13]. In view of steadily increasing demand of MPs quality and safety, more attention should be paid to the plant health.

\section{AIM}

The aim of this review was to discuss complexed relationships between microscopic fungi and medicinal plants applied in neurological diseases and mental disorders. On the one hand, microscopic fungi can strongly decrease the quality of MPs raw material. Many species of pathogenic fungi infect such plants: herbs, shrubs or trees. Among pathogens, especially fungi producing mycotoxins (i.e. Fusarium spp., Alternaria spp., Penicillium spp.) cause serious diseases of these plants, decreasing yield and quality of herbal raw material $[14,15]$. Paradoxically, people trying to use them in the treatment can be exposed to fatal mycotoxin activity. On the other hand, some microscopic fungi and their metabolites can be a kind of added value. Tissues of some MPs residue (asymptomatic) in endophytic fungi. What is interesting, that they are able to influence a biosynthesis of secondary metabolites in their host plant or produce biologically active compounds, i.e. be useful in the treatment of neurological diseases and mental disorders. Until recent times, these microorganisms were considered to be a 'component' of medicinal plants. That is a reason why there still are a trove of unexplored bioactivity and biodiversity. Currently, the endophytic fungi are expected to be a potential source of natural bioactive compounds with a huge medicinal potential $[16,17]$. This fungal-plant interaction is even more complicated considering that in tissue of MPs can exist fungal species able to biosyntheses mycotoxins as well as valuable biologically active compounds.

To summarize, in this review we try to show the influence of pathogenic and endophytic fungi on quality and usefulness of medicinal plants applied to cure neurological and mental disorders.

\section{Medicinal plants applied in management of neurological diseases and mental disorders}

Many species of medicinal plants are recommended for neurological diseases and mental disorders (tab. 1). Herbs popular in Europe such as Melissa officinalis L., Valeriana officinalis L., Hypericum perforatum L., Matricaria chamomilla L. and Ocimum basilicum L. are used in anxiety, insomnia, anxiety and depression.

Lemon balm (Melissa officinalis L.) is used for Alzheimer's disease (aromatherapy), attention deficithyperactivity disorder (ADHD), accelerated heartbeat and high blood pressure due to nervousness [18]. 
Table 1.

Medicinal plants applied to cure neurological diseases and mental disorders

\begin{tabular}{|c|c|c|c|c|}
\hline Medicinal plant species & $\begin{array}{l}\text { Family of medicinal } \\
\text { plant species }\end{array}$ & Common name & Popular use & References \\
\hline Ocimum basilicum L. & Lamiaceae & sweet basil & headaches & 43 \\
\hline Melissa officinalis L. & Lamiaceae & lemon balm & $\begin{array}{l}\text { Alzheimer's disease } \\
\text { attention deficit-hyperactivity } \\
\text { disorder (ADHD) } \\
\text { nervousness }\end{array}$ & 18 \\
\hline Hypericum perforatum $\mathrm{L}$. & Hypericaceae & St. John's wort & depression & 19 \\
\hline Valeriana officinalis $L$. & Valerianaceae & valerian & $\begin{array}{l}\text { nervous excitability } \\
\text { pain } \\
\text { migraine } \\
\text { anxiety }\end{array}$ & $21,44,45$ \\
\hline Cannabis sativa $\mathrm{L}$. & Cannabaceae & hemp & $\begin{array}{l}\text { depression } \\
\text { anxiety } \\
\text { pain alleviation }\end{array}$ & 22,23 \\
\hline Angelica archangelica L. & Apiaceae & garden angelica & disorders of nervous system & 24 \\
\hline Galanthus nivalis L. & Amaryllidaceae & snowdrop & Alzheimer's disease & 25 \\
\hline Lavandula angustifolia $\mathrm{L}$. & Lamiaceae & lavender & $\begin{array}{l}\text { strengthening of the nervous } \\
\text { system }\end{array}$ & $\begin{array}{l}20,26 \\
27\end{array}$ \\
\hline Matricaria chamomilla L. & Asteraceae & wild chamomile & $\begin{array}{l}\text { stress } \\
\text { depression } \\
\text { insomnia } \\
\text { anxiety }\end{array}$ & $1,28,29,42$ \\
\hline Mentha piperita L. & Lamiaceae & peppermint & $\begin{array}{l}\text { insomnia } \\
\text { depression }\end{array}$ & 33,34 \\
\hline $\begin{array}{l}\text { Platycodon grandiflorus (Jacq.) } \\
\text { A.DC. }\end{array}$ & Campanulaceae & ballon flower & $\begin{array}{l}\text { neuroprotective } \\
\text { nervous excitability }\end{array}$ & 35,36 \\
\hline Salvia officinalis L. & Lamiaceae & sage & Alzheimer's disease & 37 \\
\hline Viburnum tinus L. & Adoxaceae & laurustinus & depression & 38 \\
\hline Piper nigrum $\mathrm{L}$. & Piperaceae & black pepper & $\begin{array}{l}\text { nervous excitability } \\
\text { anxiety }\end{array}$ & 39 \\
\hline Ginkgo biloba L. & Ginkgoaceae & ginkgo & $\begin{array}{l}\text { Alzheimer's disease } \\
\text { depression }\end{array}$ & 40,41 \\
\hline
\end{tabular}

St. John's Wort (Hypericum perforatum L.) is a herb which thanks to its active compound, hypericin, works as a dopamine-related antidepressant commonly used for its neurological effects $[19,20]$.

Valeriana officinalis L. is well known for its sedative and anticonvulsant qualities and its ability to relax the central nervous system and the smooth muscle groups (pain reliever) used as a sedative, in migraine treatment, and as a pain reliever [21].

One of interesting natural sources of compounds used to relieve different types of pain and for protection of nervous system is extract from Cannabis sativa L. without psychotropic cannabinoids. Medicinal properties of C. sativa have been explored for centuries. It is well established that active compounds of this herb act through two cannabinoid receptors (CB1,
CB2) [22]. Health benefits are well documented, from depression and anxiety relief to reduced blood pressure, pain alleviation and glaucoma treatment. It is not addictive, does not kill brain cells $[22,23]$.

The roots of garden angelica (Angelica archangelica L.) are used in the traditional Austrian medicine internally as tea or tincture for treatment of disorders of nervous system and also for the gastrointestinal and respiratory tracts. This herb works calmingly [24].

Snowdrop (Galanthus nivalis L.) is a well-known medicinal plant. It contains an active substance called galantamine, which is an acetylcholinesterase inhibitor. Galantamine (or galanthamine) can be helpful in the treatment of Alzheimer's disease, however, it is not a cure [25]. 
Lavender (Lavandula angustifolia L.) has healing properties. It has been traditionally used as an antiseptic and for mental health purposes. There are some scientific evidence that lavender is effective for most mental health uses [20, 26, 27].

Chamomilla (Matricaria chamomilla L.) has been used over thousands of years for a variety of conditions, including insomnia, anxiety, and gastrointestinal conditions such as upset stomach, gas, and diarrhea $[1,28]$. Inhalation of the vaporized essential oils derived from chamomile flowers is recommended to relieve anxiety and general depression [7].

Mentha piperita L. has a history of medicinal use for a variety of conditions, including not only nausea, indigestion but insomnia and depression [29-34]. The extracts and purified platycoside compounds (saponins) from the roots of Platycodon grandiflorus may exhibit neuroprotective, antimicrobial, anti-inflammatory, anti-cancer, anti-allergy, improved insulin resistance, and cholesterol-lowering properties $[35,36]$.

Salvia officinalis L. has influence to improve cognitive function in patients with mild to moderate Alzheimer's disease [37].

Viburum tinus L. has also medicinal properties. The active ingredients are viburnin (a substance or more probably a mixture of compounds) and tannins. Tannins can cause dyspepsia. Infused leaves have antipyretic properties. The fruits have been used as purgatives against constipation. Lately, the tincture has been used in herbal medicine as a remedy for depression. The plant also contains iridoid glucosides [38].

A constituent of pepper (Piper nigrum L.) - piperine, protects against oxidative damage by inhibiting free radicals and reactive oxygen species. Piperine has also sedative properties [39].

Ginkgo (Ginkgo biloba L.) is one of the oldest living tree species. It is also one of the best-selling herbal supplements in the United States and Europe. G. $b i$ loba leaf is often administered orally for memory disorders including Alzheimer's disease. It is also used for conditions that seem to be due to reduced blood flow in the brain, especially in elderly. Ginkgo leaf is also used for thinking disorders related to Lyme disease, chemotherapy, and depression [40, 41].

\section{Pathogenic and toxigenic fungi infecting medici- nal plants}

Fungi are the primary cause of medicinal plant diseases. Considering MPs properties for treatment or prevention of human diseases the most important are fungal species which biosyntheses toxic substances (tab. 2). Mycotoxins are highly toxic secondary metabolic products of fungi, mainly those belonging to genera Fusarium, Aspergillus, Penicillium and Alternaria. It has been estimated that about 300 of these fungal metabolites are toxic to animals and humans [46].

Alternaria are a well-known and commonly occurring plant pathogens. This fungus infects species of herbal plants very often. It occurs on raw herbal material, despite the lack of evidence of infestation [47]. Species of Alternaria can produce toxins associated with animal and human disorders. Most of the toxins produced by Alternaria are dangerous to human health. The most studied is tenuazonic acid. The principal mode of action is the inhibition of protein synthesis. Alternariol and alternative monomethyl ether exhibit phytotoxic, teratogenic and mutagenic effects $[48,49]$.

The presence of a number of species from the Fusarium genus has been found on many herbal plants. Fusarium species were isolated from different parts of $O$. basilicum, $H$. perforatum, A. archangelica, $M$ chamonilla, G. biloba, M. pipperita, V. oficinalis, and C. sativa [50-57].

Fusarium species also produce mycotoxins harmful to human health. These are: trichotecenes, zearalenone, fumonisins, moniliformin, aflatoxin [58-60]. Acute mycotoxicosis caused by high doses of micotoxins is rarely observed in humans. However, even low amounts may impair intestinal health, immune function and/or pathogen fitness, resulting in altered host pathogen interactions and thus a different outcome of infection [58, 61, 62]. Accumulation of mycotoxins produced by Fusarium fungi can cause, for example, colibacillosis and salmonellosis, as well as inflammation of intestines [63-66].

Species from the Aspergillus genus are also found on herbal plants (tab. 1). These fungi grow in the vegetation period of plants as well as on the raw material stored in inappropriate conditions [67]. Pathogenic Aspergillus spp. also produces mycotoxins. These toxins are known for their strong and varied biological activities. For example, aflatoxin, the well-known and well-investigated mycotoxin, is known to carry the most potent carcinogenic activity as a natural product. It also carries acute toxicity to various human cells such as hepatocytes, renal cells, lung epithelioid cells, etc., as well as various immunosuppressive 
Table 2.

Fungal species that biosynthese toxic substances documented in medicinal plants

\begin{tabular}{|c|c|c|c|}
\hline Fungal species & Mycotoxins & Infected medicinal plants & Reference \\
\hline \multirow[t]{4}{*}{ Alternaria } & \multirow{4}{*}{$\begin{array}{l}\text { Alternariol } \\
\text { Monomethyl ether Altenuene } \\
\text { Altertoxins I, II, III } \\
\text { Tenuazonic acid }\end{array}$} & Salvia officinalis L. & $79-81$ \\
\hline & & Hypericum perforatum $\mathrm{L}$. & \\
\hline & & Ginkgo biloba $\mathrm{L}$. & 82,83 \\
\hline & & Mentha pipperita L. & 47,84 \\
\hline \multirow[t]{4}{*}{ Aspergillus } & \multirow{4}{*}{$\begin{array}{l}\text { Aflatoxin } \\
\text { Ochratoxin } \\
\text { Gliotoin } \\
\text { Fumagilin } \\
\text { Helvalic acid } \\
\text { Fumitrenorgin A } \\
\text { Asp-hemolysin }\end{array}$} & Matricaria chamomilla L. & $57,58,67$ \\
\hline & & Mentha piperita L. & \\
\hline & & Melissa officinalis L. & \\
\hline & & & \\
\hline \multirow[t]{9}{*}{ Fusarium } & \multirow{9}{*}{$\begin{array}{l}\text { Trichotecenes } \\
\text { Zearalenone } \\
\text { Fumonisins } \\
\text { Moniliformin } \\
\text { Aflatoxin }\end{array}$} & Ocimum basilicum L. & $50-53,55,85$ \\
\hline & & Hypericum perforatum $\mathrm{L}$. & $53-55$ \\
\hline & & Melissa officinalis L. & 56,57 \\
\hline & & Angelica archangelica L. & 86,87 \\
\hline & & Matricaria chamomilla L. & 88 \\
\hline & & Ginkgo biloba L. & $58,82,83$ \\
\hline & & Mentha piperita L. & 51 \\
\hline & & Valeriana officinalis L. & 56,57 \\
\hline & & Cannabis sativa $\mathrm{L}$. & 32 \\
\hline \multirow[t]{4}{*}{ Penicillium } & \multirow{4}{*}{$\begin{array}{l}\text { Penicilic acid } \\
\text { Citrinin } \\
\text { Patulin }\end{array}$} & Hypericum perforatum $\mathrm{L}$. & 81 \\
\hline & & Salvia officinalis $\mathrm{L}$. & 79 \\
\hline & & Valeriana officinalis $\mathrm{L}$. & $56,57,77$ \\
\hline & & Matricaria chamomilla L. & 67,91 \\
\hline
\end{tabular}

activities [63, 64, 68]. Species form the genus Aspergillus produce mainly: aflatoxin, ochratoxin, gliotoin, fumagilin, helvalic acid, fumitrenorgin A, asp-hemolysin [69-75].

Species of the Penicillium genus are probably best known as dangerous to human health. There are several dozen species of this pathogen. Many of these species live on herbal plants and produce mycotoxins. Mycotoxins produced by Penicillium species are: penicilic acid, citrinin and patulin [76-78]. This causes accumulation of produced mycotoxins in herbal raw material. These toxins are of a carcinogenic effect [63].

\section{Metabolic activity of endophytic fungi infesting medicinal plants}

Endophytes are polyphyletic group of diverse, primarily ascomycetous fungi capable of asympto- matic infestation of apparently healthy plant tissue [92]. Therefore, a fungus can be considered to be endophyte after the demonstration of its hyphae in the living tissue. The term 'endophyte' (Gr. endon, within phyton, plant) was first used by de Bary in 1866 [93]. The existence of fungi inside the plants tissues without causing any identifiable disease symptoms to the host has been known since the end of the $19^{\text {th }}$ century. Endophytes are synergistic to their host plant [94]. Over the long evolution, co-existing endophytes and their host plants have established a unique relationship which can significantly influence the formation of metabolic products in plants [95]. Plants inhabited with specific endophyte became stronger and able to grow faster due to, for example, production of phytohormones [96-99]. The bioactive metabolites belong to diverse chemical groups such as alkaloids, steroids, flavonoids, terpenoids, quinones, lactones etc. [96]. Faeth and Fagan [97] notified that endophytic fungi have played a very important role in affecting the 
Table 3.

Host medicinal plants common in Europe and endophytic fungi producing plant-secondary metabolites

\begin{tabular}{|c|c|c|c|c|}
\hline Host medicinal plant & Fungal endophyte & Secondary metabolite & Bioactivity & References \\
\hline \multirow[t]{2}{*}{ Hypericum perforatum $\mathrm{L}$. } & Chaetomium globosum & hipericin & anti-depressant & 104 \\
\hline & Thielavia subthermophila & $\begin{array}{l}\text { hipericin } \\
\text { emodin }\end{array}$ & $\begin{array}{l}\text { anti-depressant } \\
\text { anti-cancer }\end{array}$ & 105 \\
\hline Piper nigrum $\mathrm{L}$. & Colletotrichum gleosporioides & piperine & anti-depressant & 106 \\
\hline \multirow[t]{4}{*}{ Gingko biloba L. } & Alternaria sp. & paclitaxel & anti-cancer & 83 \\
\hline & Aspergillus nidulans & quercetin & anti-inflammatory & 107 \\
\hline & Fusarium oxysporum & gingkolide & anti-allergic & 83 \\
\hline & Pestalotiopsis uvicola & bilobalide & neuroprotective & 107 \\
\hline
\end{tabular}

quality and quantity of the crude drugs through a particular fungus-host interaction.

Research on the biosynthetic potential of endophytes was accelerated after discovery of fungal strains capable to synthesize de novo various bioactive compounds previously considered as host plant products [100]. For the first time, such possibility was comprehended and published by Stierle et al. [101], following the discovery of endophytic Taxomyces andreanae that produces anticancer compound called paclitaxel, which was isolated from Taxus brevifolia. The success of obtaining fungal taxol has initiated a lot of studies focused on microorganisms able to produce metabolites displaying antitumor bioactivity $[100,101]$. More than 100 anticancer compounds have been reported alone from fungal endophytes in 1990-2010 [101]. Unfortunately, the knowledge about endophytes from herbs applied to cure neurological and psychiatric illness remain still limited, especially considering medicinal plants cultivated and common used in Europe (tab. 3).

An example of interesting medicinal plant-endophyte relationship is Hypericum perforatum and Tielavia subthermophila. $H$. perforatum produces hypericin (2,2'-dimethyl-4,4',5,5',7,7'-hexahydroxymesonaphtodianthrone), a photodynamic, redcoloured anthraquinone-derivative [102] which is synthesized in the specialized glandular structures dispersed over all above-ground parts of the plant [103-105] discovered endophytic fungus that have been evolutionarily co-adapted to protect itself from the photodynamic effects and produce hypericin even in axenic cultures. The hyp-1 gene, suggested to encode for the Hyp-1 phenolic coupling protein in plant cell cultures, was not found in endophyte genome. Kusari et al. [105] proposed that emodin anthrone is the common precursor of both hypericin and emodin in the fungal endophyte, which is governed by a different molecular mechanism than in the $H$. perforatum. Thus, the metabolic activity of endophyte increases hypericin content in plant crude extract.

Piper nigrum is pharmaceutically remarkable because of the presence of the alkaloid: piperine that exhibits broad bioactive properties ranging from antidepressant to anticancer activities. Chithra et al. [106] found the isolate belonging to Colletotrichum gloeosporioides species complex that was able to biosyntheses piperine. It is worth mentioning that C. gleosporioides is known as a pathogenic fungus causing anthracnose and fruit rot on hundreds of economically important host plants. This highlights the complexity of plant-fungal interaction.

Recently, studies on new biologically-active metabolites from endophytic microorganisms residing in a well-known medicinal plant Gingko biloba have shown that some endophytes belonging to Alternaria and Aspergillus genera produce anticancer and anti-oxidant secondary metabolites but no anti-depressant fungal product was detected [107]. Cui et al. [108] explore an endophytic fungus Fusarium oxysporum, isolated from G. biloba, with the capability to produce biologically active ginkgolide B. Qian et al. [83] proved that endophytic fungus Pestalotiopsis uvicola isolated from G. biloba leaves can produce bilobalide, identical like this produced by host plant.

Undoubtedly, many unknown fungal endophytes capable to produce other associated plant secondary metabolites are of therapeutic influence on human nervous system. They still remain to be discovered and characterized. 


\section{CONCLUSIONS}

Coexistence of fungi and medicinal plants is not fully understood but can be crucial to ensure health and safety of neurological and psychiatric patients. On the one hand, pathogenic fungi can cause plant diseases decreasing quantity and quality of yield. Some of them biosynthesise secondary metabolites toxic to plants or affect human health. Paradoxically, within some fungal species (i.e. F. oxysporum), isolates producing mycotoxins as well as isolates able to produce valuable bioactive compounds can be found [103].

Endophytic fungi isolated from plant tissues seems to be not fully understood but promising source of bioactive compounds. The production of therapeutic secondary metabolites by endophytic fungi nurtures expectations of use as alternative sources of these valuable compounds. However, commercial production of desirable substances by endophytic fungi seems to remain a distant future. The biotechnological application of endophytes is hampered by suppression of secondary metabolite production on repeated subculturing under axenic monoculture conditions [104]. Moreover, even slight changes in the in vitro cultivation conditions can impact the kind and range of secondary metabolites they produce [104]. More understanding of the particular relationships between endophytic fungi and medicinal plants recommended for neurological diseases and mental disorders is required.

Ethical approval: The conducted research is not related to either human or animal use.

Conflict of interest: Authors declare no conflict of interest.

\section{REFERENCES}

1. Blumenthal M, Goldberg A, Brinckmann J. Herbal Medicine: Expanded Commission E Monographs. Newton, MA: Integrative Medicine Communications, eds. 2002; 123-129.

2. Calvo MI, Cavero RY. Medicinal plants used for neurological and mental disorders in Navarra and their validation from official sources. J Ethnopharm 2015; 169:263-268. doi: http://dx.doi. org/10.1016/j.jep.2015.04.035

3. Romeiras MM, Duarte MC, Indjai B, Catarino L. Medicinal plants use to treat neurological disorders in West Africa: a case study with Guinea-Bissau flora. Am J Plant Sci 2012; 3:1028-1036. doi: http://dx.doi.org/10.4236/ajps.2012.327122
4. Newman DJ, Cragg GM, Snader KM. Natural products as sources of new drugs over the period 1981-2002. J Nat Prod 2003; 66:1022-1037. doi: http://dx.doi.org/10.1021/np0300961

5. Jones WP, Chin YW, Kinghorn AD. The role of pharmacognosy in modern medicine and pharmacy. Curr Drug Targets 2006; 7:247-264.

6. Máthé A. Medicinal and aromatic plants of the world: scientific, production, commercial and utilization aspects. $1^{\text {st }}$ ed. Springer 2015; pp. 448.

7. Srivastava JK, Shankar E, Gupta S. Chamomile: A herbal medicine of the past with bright future. Mol Med Rep 2010; 3(6):895-901. doi: http:// dx.doi.org/10.3892/mmr.2010.377

8. Verkhratsky A, Parpura V. Neurological and psychiatric disorders as a neurological failure. Period Biol 2014; 116(2):115-124.

9. WHO 2001; www.who.int.whr/2001/media-center/en/whr01_fact_sheet1_enpdf

10. WHO 2017; http://www.who.int/mental_health/ mhgap/en/

11. Bussmann RW. The globalization of traditional medicine in Northern Peru: from shamanism to molecules. Evid-Based Complement Alter Med 2013; 2013:1-46. doi: http://dx.doi. org/10.1155/2013/291903

12. Bögels S, Knappe S, Clark LA. Adult separation anxiety disorder in DSM-5. Clin Psychol Rev 2013;33:663-674. doi: http://dx.doi.org/10.1016/j. cpr.2013.03.006

13. Thorp SR, Ayers CR, Nuevo R. Meta-analysis comparing different behavioral treatments for late-life anxiety. Am J Geriatr Psychiatry 2009; 17:105-115. doi: http://dx.doi.org/10.1097/ JGP.0b013e31818b3f7e

14. Irzykowska L, Bocianowski J, Waśkiewicz A, Weber Z, Golinski P, Karolewski Z et al. Genetic variation of Fusarium oxysporum isolates forming fumonisin B1 and moniliformin. J Appl Genet 2012; 53:237-247. doi: http://dx.doi.org/10.1007/ s13353-012-0087-z

15. Machowicz-Stefaniak Z, Gabler J, Zalewska E. Patogeny zagrażające uprawie roślin zielarskich/ Pathogens threaten the cultivation of herb plants. Folia Hortic Supl 2003; 1:565-567. 
16. Li XY, Qing C, Zhang YL, Zhao ZW. Screening for endophytic fungi with anti-tumor and antifungal activities from Chinese medicinal plants. World J Biotechnol 2005; 21:1515-1519. doi: http://dx.doi.org/10.1007/s11274-005-7381-4

17. Michalczyk A, Cieniecka-Rosłonkiewicz A, Cholewińska M. Plant endophytic fungi as a source of paclitaxel, Herba Pol 2014; 60(4):22-33. doi: http://dx.doi.org/10.1515/hepo-2015-0002

18. Szczeponek A, Mazur S. Occurence of fungal diseases on lemon balm (Melissa officinalis L.) and peppermint (Mentha piperita L.) in the region of Malopolska. Commun Agric Appl Biol Sci 2006; 71(3B):1109-1118.

19. Greeson JM, Stanford B, Monti DA. St. John's wort (Hypericum perforatum): a review of the current pharmacological, toxicological, and clinical literature. Psychopharmacology 2001; 153:402-414. doi: http://dx.doi.org/10.1007/s002130000625

20. Dwyer AV, Whitten DL, Hawrelak JA. Herbal medicines, other than St. John's wort, in the treatment of depression: a systematic review. Alternat Med Rev 2011; 16(1):40-49.

21. Boullata A, Joseph I, Nace S, Angela M. Safety issues with herbal medicine: common herbal medicines. Pharmacotherapy 2000; 20(3):257-269. doi: http://dx.doi.org/10.1592/phco.20.4.257.34886

22. Vigano D, Rubino T, Parolaro D. Molecular and cellularbasis of cannabinoid and opioid interactions. Pharmacol Biochem Behav 2005; 81:360-368. doi: http://dx.doi.org/10.1016/j.pbb.2005.01.021

23. Mechoulam R, Hanus L. Cannabidiol: an overview of some chemical and pharmacological aspects. Part I: chemical aspects. Chem Phys Lipids 2002; 121:35-43. doi: http://dx.doi.org/10.1016/ S0009-3084(02)00144-5

24. Marcello I, Sara V, Gelsomina F, Franco F. Neuroprotective, herbs and foods from different traditional medicines and diets. Molecules 2010; 15:3517-3555.

25. Loy C, Schneider L. Galantamine for Alzheimer's disease and mild cognitive impairment. Cochrane Database Syst Rev 2006; 25(1):CD001747. doi: http://dx.doi.org/10.1002/14651858.CD001747. pub3
26. Henley DV, Lipson N, Korach KS. Prepubertal gynecomastia linked to lavender and tea tree oils. New Eng J Med 2007; 356(5):479-485.

27. Perry R, Terry R, Watson LK, Ernst E. Is lavender an anxiolytic drug? A systematic review of randomised clinical trials. Phytomedicine 2012; 19(8-9):825-835. doi: http://dx.doi.org/10.1016/j. phymed.2012.02.013

28. Gardiner P. Complementary, holistic, and integrative medicine: chamomile. Pediatr Rev 2007; 28(4):e16-e18.

29. Amsterdam JD, Li Y, Soeller I. A randomized, double-blind, placebo-controlled trial of oral Marticaria recutita (chamomile) extract therapy of generalized anxiety disorder. J Clinic Psychopharmacol 2009; 29(4):378-382.

30. Ford AC, Talley NJ, Spiegel BM, Effect of fibre, antispasmodics, and peppermint oil in the treatment of irritable bowel syndrome: systematic review and meta-analysis. BMJ 2008; 337:a2313. doi: http://dx.doi.org/10.1136/bmj.a2313

31. Kligler B, Chaudhary S. Peppermint oil. Am Family Physic 2007; 75(7):1027-1030.

32. McKay DL, Blumberg JB. A review of the bioactivity and potential health benefits of peppermint tea (Mentha piperita L.). Phytother Res 2006; 20(8):619-633. doi: http://dx.doi.org/10.1002/ ptr.1936

33. Ravid U, Putievsky EI. Enantiomeric distribution of piperitone in essential oils of some mentha spp., Calamintha incana (sm.) heldr. and Artemisia indaica. Flavour Fragrance J 1994; 9:85-87.

34. Tassou CC, Drosinos EH, Nychas GJ. Effects of essential oil from mint (Mentha piperita) on Salmonella enteritidis and Listeria monocytogenes in model food system at 4 degrees and 10 degrees $C$. J Appl Bacteriol 1995; 78(6):593-600.

35. Lee JY, Hwang WI, Lim ST. Antioxidant and anticancer activities of organic extracts from Platycodon grandiflorum A. De Candolle roots. J Ethnopharmacol 2004; 93:409-415. doi: http:// dx.doi.org/10.1016/j.jep.2004.04.017

36. Cacabelos R. Alzheimer disease. Rev Med Pract Clin 1997; 2:124-142. 
37. Akhondzadeh S, Noroozian M, Mohammadi M, Ohadinia S, Jamshidi AH, Khani M. Salvia officinalis extract in the treatment of patients with mild to moderate Alzheimer's disease: A double blind, randomized and placebo-controlled trial. J Clin Pharm Therap 2003; 28(1):53-9. doi: http:// dx.doi.org/10.1046/j.1365-2710.2003.00463.x

38. Tomassini LM, Cometa F, Foddai S, Nicoletti M. Iridoid glucosides from Viburnum tinus. Phytochemistry 1995; 38(2):423-425. doi: http://dx.doi. org/10.1016/0031-9422(94)00618-4

39. Vasanthi H, Parameswari RP. Indian spices for healthy heart. Curr Cardiol Rev 2010; 6(4):274279. doi: http://dx.doi.org/10.2174/1573403107 93566172

40. Ashton AK, Ahrens K, Gupta S, Masand PS. Antidepressant-induced sexual dysfunction and Ginkgo biloba. Am J Psychiatry 2000; 157(5):836-837. doi: http://dx.doi.org/10.1176/appi.ajp.157.5.836

41. Van Dongen M, van Rossum E, Kessels A, Sielhorst H, Knipschild P. Ginkgo for elderly people with dementia and age-associated memory impairment: a randomized clinical trial. J Clin Epidemiol 2003; 56(4):367-376. doi: http://dx.doi. org/10.1016/S0895-4356(03)00003-9

42. Pinto SA, Bohland E, Coelho Cde P, Morghulis MS, Bonamin LV. An animal model for the study of Chamomilla in stress and depression: pilot study. Homeopathy 2008; 97:141-4. doi: http:// dx.doi.org/10.1016/j.homp.2008.04.001

43. Telci I, Bayram E, Yilmaz G, Avci B. Variability in essential oil composition of Turkish basils (Ocimum basilicum L.). Biochem Syst Ecol 2006; 34:489-497. doi: http://dx.doi.org/10.1016/j. bse.2006.01.009

44. Hobbs C. Valerian and other anti-hysterics in European and American medicine. 1996. Herbal Medicine. Health World Online. http://www. healthy.net/hwlibraryarticles/hobbs/valer4.htm

45. Hendriks H, Bos R, Allersma DP, Malingré ThM, Koster ASj. Pharmacological screening of valerenal and some other components of essential oil of Valeriana officinalis. Planta Med 1981; 42:62-68.

46. Heidler D, Schatzmayr GA. New approach to managing mycotoxins. World Poult Reed 2003; 19(2):12-15.
47. Datta R, Deepak K, Chattopadhyay S. Membrane proteome profiling of Mentha arvensis leaves in response to Alternaria alternata infection identifies crucial candidates for defense response. Plant Sign Behav 2016; doi: http://dx.doi.org/10.1080/1 5592324.2016 .1178423

48. James RC. General principles of toxicology, p.726. (In:) PL. Williams and JL. Burson (eds.), Industrial toxicology. New York 1985.

49. Meronuck RA, Steele J, Mirocha CJ. Tenuazonic acid, a toxin produced by Alternaria alternata. Appl Microbiol 1972; 23(3):613-617.

50. Minuto A, Minuto G, Migheli Q, Mocioni M, Gullino ML. Effect of antagonistic Fusarium spp. and different commercial biofungicide formulations on Fusarium wilt of basil (Ocimum basilicum L.). Crop Protect 1997; 16:765-9.

51. Trueman SL, Wick RL, Fusarium wilt of herbs. Acta Hortic 1996; 426:41-56. doi: http://dx.doi. org/10.17660/ActaHortic.1996.426.41.

52. Machowicz-Stefaniak Z, Zalewska E, Zimowska B. Grzyby zasiedlające nadziemne organy melisy lekarskiej Melissa officinalis L. i tymianku właściwego Thymus vulgaris L. uprawianych na Lubelszczyźnie [Fungi colonizing above-ground parts of lemon balm Melissa officinalis L. and thyme Thymus vulgaris L. cultivated in the Lublin region]. Folia Univ Agric Stetin Agricultura 2004; 239(95):229-232.

53. Zimowska B, Machowicz-Stefaniak Z. Fungi threatening with cultivation of St. John's Wort (Hypericum perforatum L.) in the Lublin province. Acta Sci Pol Hort Cultus 2004; 3(1):61-74.

54. Lewis L, Onsongo M, Njapau H, Schurz-Rogers H, Luber G, Kieszak S, et al. Aflatoxin contamination of commercial maize products during an outbreak of acute aflatoxicosis in eastern and central Kenya. Environ Health Perspect 2005; 113(12):1763-7. doi: http://dx.doi.org/10.1289/ehp.7998

55. Rekosz-Burlaga H, Borys M, Goryluk-Salmonowicz A. Cultivable microorganisms inhabiting the aerial parts of Hypericum perforatum. Acta Sci Pol Hort Cultus 2014; 13(5):117-129.

56. Zalewska E, Machowicz-Stefaniak Z. Patogeniczność grzybów z rodzaju Fusarium dla melisy le- 
karskiej (Melissa officinalis L.). Acta Sci Pol Hort Cultus 2004; 3:33-9.

57. Wielgusz K, Seidler-Łożykowska K. Fungi colonizing and damaging different parts of some medicinal plants. Herba Pol 2017; 63(2):18-26. doi: http://dx.doi.org/10.1515/hepo-2017-0009

58. D’Mello J, Placinta C, Macdonald A. Fusarium mycotoxins: A review of global implications for animal health, welfare and productivity. Anim Feed Sci Tech 1999; 80:183-205. doi: http:// dx.doi.org/10.1016/S0377-8401(99)00059-0

59. Maresca M, Fantini J. Some food-associated mycotoxins as potential risk factors in humans predisposed to chronic intestinal inflammatory diseases. Toxicon 2010; 56:282-294. doi: http:// dx.doi.org/10.1016/j.toxicon.2010.04.016

60. Maresca M. From the gut to the brain: Journey and pathophysiological effects of the food-associated trichothecene mycotoxin deoxynivalenol. Toxins 2013; 5:784-820. doi: http://dx.doi. org/10.3390/toxins5040784

61. Devriendt B, Verdonck F, Wache Y, Bimczok D, Oswald IP, Goddeeris BM, et al. The food contaminant fumonisin $\mathrm{B} 1$ reduces the maturation of porcine CD11r1+ intestinal antigen presenting cells and antigen-specific immune responses, leading to a prolonged intestinal ETEC infection. Vet Res 2009; 40:1-14. doi: http://dx.doi. org/10.1051/vetres/2009023

62. Zain ME. Impact of mycotoxins on humans and animals. J Saudi Chem Soc 2011; 15:129-144. doi: http://dx.doi.org/10.1016/j.jscs.2010.06.006

63. Smith TK, Diaz G, Swamy H. Current Concepts in Mycotoxicoses in Swine. In: Diaz DE (ed.) The Mycotoxin Blue Book. Nottingham University Press; Nottingham, UK: 2005:235-248.

64. Devegowda G, Murthy T. Mycotoxins: Their Effects in Poultry and Some Practical Solutions. In: Diaz D.E. ed. The Mycotoxin Blue Book. Nottingham University Press; Nottingham 2005; 25-56.

65. Andrews-Polymenis HL, Bäumler AJ, McCormick BA, Fang FC. Taming the elephant: Salmonella biology, pathogenesis, and prevention. Infect Immun 2010; 78:2356-2369. doi: http:// dx.doi.org/10.1128/IAI.00096-10
66. Martel GA, Pasmans F, Ducatelle R, Verbrugghe E, Vandenbroucke V, Li S et al. The impact of Fusarium mycotoxins on human and animal host susceptibility to infectious diseases. Toxina (Basel) 2014; 6(2):430-452. doi: http://dx.doi. org/10.3390/toxins6020430

67. Bottcher H, Gunther I. Storage of dry drug. In: Franke R, Schilcher H. Chamomile: industrial profiles. 1st ed. Boca Raton: CRC Press; 2005:211230.

68. Lioi M, Santoro A, Barbieri R, Salzano S, Ursini M. Ochratoxin A and zearalenone: a comparative study on genotoxic effects and cell death induced in bovine lymphocytes. Mutat Res 2004; 557:19-27.

69. Muller G, Burkert B, Moller U, Diller R, Rohrmann B, Rosner $\mathrm{H}$, et al. Ochratoxin A and some of its derivatives modulate radical formation of porcine blood monocytes and granulocytes. Toxicology 2004; 199:251-259.

70. Muller G, Rosner H, Rohrmann B, Diller R, Rosner $\mathrm{H}$, Kohler K. Effects of the mycotoxin ochratoxin A and some of its metabolites on the human cell line THP-1. Toxicology 2003; 184:69-82.

71. Kumagai T, Nagata T, Kudo Y, Fukuchi Y, Ebina $\mathrm{K}$, Yokata K. Cytotoxic activity and cytokine gene induction of Asp-hemolysin to murine macrophages. Nippon Ishinkin Gakkai Zasshi 1999; 40:217-222.

72. Kumagai T, Nagata T, Kudo Y, Fukuchi Y, Ebina $\mathrm{K}$, Yokata K. Cytotoxic activity and cytokine gene induction of Asp-hemolysin to vascular endothelial cell. Yakugaku Zasshi 2001; 121:271-275.

73. Müllbacher A, Waring P, Eichner R. Identification of an agent in cultures of Aspergillus fumigatus displaying anti-phagocytic and immunomodulating activity in vitro. J Gen Microbiol 1985; 131:1251-1258.

74. Klich MA, Mullaney EJ, Daly CB, Cary JW. Molecular and physiological aspects of aflatoxin and sterigmatocystin biosynthesis by $A$. tamarii and A. ochraceoroseus. Appl Microbiol Biotechnol 2000; 53:605-622.

75. Goto T, Wicklow DT, Ito Y. Aflatoxin and cyclopiazonic acid production by a sclerotium-producing Aspergillus tamarii strain. Appl Environ Microbiol 1996; 62:4036-4038. 
76. Bentley R, Bennett JW. Constructing polyketides: from Collie to combinatorial biosynthesis. Annu Rev Microbiol 1999; 53:411-446. doi: http:// dx.doi.org/10.1146/annurev.micro.53.1.411

77. Hetherington AC, Raistrick H. Studies in the biochemistry of microorganisms. Part XIV. On the production and chemical constitution of a new yellow colouring matter, citrinin, produced from glucose by Penicillium citrinum. Thom Phil Trans R Soc London 1931. Ser. B 220B:269-295.

78. Wilson BJ, Harris TM, Hayes AW. Mycotoxin from Penicillium puberulum. J Bacteriol 1967; 93(5):1737-1738.

79. Zimowska B. Fungi threatening the cultivation of sage (Salvia officinalis L.) in south-eastern Poland. Herba Pol 2008; 54(1):14-21.

80. Logrieco A, Moretti A, Solfrizzo M. Alternaria toxins and plant diseases: an overview of origin, occurrence and risks. World Mycotoxin J 2009; 2(2):129-140. doi: http://dx.doi.org/10.3920/ WMJ2009.1145

81. Radaitiene D, Kacergius A, Radusiene J. Fungal diseases in Hypericum perforatum L. and H. maculatum Crantz in Lithuania. Biologija 2002; 2:35-37.

82. Balz JP, Courtois D, Drieu J, Reynoird JP, Sohier C, Teng BP et al. Valeriana officinalis, nuovo ospite del virus dell'avvizzimento della fava (BBWV). ATTI Giornate Fitopatol 1998; 789-794.

83. Qin JC, Zhang YM, Gao JM, Bai MS, Yang SX, Laatsch $\mathrm{H}$ et al. Bioactive metabolites produced by Chaetomium globosum, an endophytic fungus isolated from Ginkgo biloba. Boorgan Med Chem 2009; 19:1572-1574.

84. Sultan SA, Sehgal M, Arora S, Singh A, Srivastava K, Yadav AS et al. Community analysis of key pests associated with mentha crop at sitapur, U.P. India. Inter J Res Engin Innov 2016; 1(2):1-6.

85. Rheeder JP, Marasas WFO, Wismer HF. Production of fumonisin analogs by Fusarium species. Appl Environ Microbiol 2002; 68:2102-2105.

86. Harmala P, Kaltia S, Vuorela H, Hiltunen R. Dihydrofuranocoumarin from Angelica archangelica. Planta Med 1992; 58:287-289.
87. Zalewska E, Machowicz-Stefaniak Z, Król E. Occurrence of fungi on angelica plants Archangelica officinalis Hoffm. Acta Sci Pol Hort Cultus 2013; 12(2):107-121.

88. Pappas AC, Elena K. Occurrence of Fusarium oxysporum f. sp. cumini in the Island of Chios, Greece. J Phytopathol 1997; 145:271-272.

89. McCain AH, Noviello C. Biological control of Cannabis sativa. Proc. VI Int. Symp Biol Contr Weeds, Vancouver 19-25 August 1985; 635-64.

90. Machowicz-Stefaniak Z, Zalewska E. Grzyby zagrażające uprawie wybranych gatunków ziół $\mathrm{z}$ rodziny Apiaceae w południowo-wschodniej Polsce [The fungi threaten to some species of herbs from Apiaceae family cultivated in SouthEast Poland]. Folia Univ Agric Stetin Agricultura 2004; 239(95):223-228.

91. Singht O, Khanam Z, Misra N, Kumar M, Srivastava K. Chamomile (Matricaria chamomilla L.): An overview. Pharmacogn Rev 2011; 5(9):82-95. doi: http://dx.doi.org/10.4103/0973-7847.79103

92. Bacon CW, White J. Microbial Endophytes, New York 2000.

93. Kusari S, Spiteller M. Metabolomics of endophytic fungi producing associated plant secondary metabolites: progress, chellenges and opportunities. In: Metabolomics. Roessner U. (ed.) InTech 2012. doi: http://dx.doi.org/10.5772/31596

94. Kaul S, Gupta S, Ahmed M, Dhar MK. Endophytic fungi from medicinal plants: a treasure hunt for bioactive metabolites. Phytochem Rev 2012; 11:487-505. doi: http://dx.doi.org/10.1007/ s11101-012-9260-6

95. Jia M, Chen L, Xin HL, Zheng CJ, Rahman K, Han T. A friendly relationship between endophytic fungi and medicinal plants: A systematic review. Front Microbiol 2016; 7:906. doi: http:// dx.doi.org/10.3389/fmicb.2016.00906

96. Zhang HW, Song YC, Tan RX. Biology and chemistry of endophytes. Nat Prot Rep 2006; 23(5):753-771. doi: http://dx.doi.org/10.1039/ b609472b

97. Faeth SH, Fagan WF. Fungal endophytes: common host plant symbionts but uncommon mu- 
tualists. Integr Comp Biol 2002; 4:360-368. doi: http://dx.doi.org/10.1093/icb/42.2.360

98. Ahmad N, Hamayun M, Khan SA, Khan AL, Lee IJ, Shin DH. Gibberellin-producing endophytic fungi isolated from Monochoria vaginalis. J Microbiol Biotechnol 2010; 20:1744-1749. doi: http://dx.doi.org/10.4014/jmb.1005.05018

99. Abd-Allah EF, Hashem A, Alqarawi A, Bahkali AH, Alwhibi MS. Enhancing growth performance and systemic aquired resistance of medicinal plant Sesbania sesban (L.) Merr using arbuscular mycorrhizal fungi under salt stress. Saudi J Biol Sci 2015; 22:274-283. doi: http://dx.doi. org/10.1016/j.sjbs.2015.03.004

100. Schulz B, Boyle C, Draeger S, Römmert AK, Krohn K. Endophytic fungi: A source of novel biologically active secondary metabolites. Mycol Res 2002; 106:996-1004. doi: http://dx.doi. org/10.1017/S0953756202006342

101. Kharwar RN, Mishra A, Gond SK, Stierle A, Stierle D. Anticancer compounds derived from fungal endophytes: their importance and future challenges. Nat Prod Rep 2011; 28:1208-1228. doi: http://dx.doi.org/10.1039/c1np00008j

102. Bais HP, Vepachedu R, Lawrence CB, Stermitz FR, Vivanco JM. Molecular and biochemical characterization of an enzyme responsible for the formation of hypericin in St. John's wort (Hypericum perforatum L.). J Biol Chem 2003; 278(34):32413-32422. doi: http://dx.doi. org/10.1074/jbc.M301681200
103. Waśkiewicz A, Goliński P, Karolewski Z, Irzykowska L, Bocianowski J, Kostecki M et al. Formation of fumonisins and other secondary metabolites by Fusarium oxysporum and F. proliferatum - a comparative study. Food Add Cont 2010; 27(5):608-615. doi: http://dx.doi. org/10.1080/19440040903551947

104. Kusari S, Lamshöft M, Zühlke S, Spiteller M. An endophytic fungus from Hypericum perforatum that produces hypericin. J Nat Prod 2008; 71:159162. doi: http://dx.doi.org/10.1021/np070669k

105. Kusari S, Lamshöft M, Zühlke S, Spiteller M. Light independent metabolomics of endophytic Thielavia subthermophila provides insight into microbial hypericin biosynthesis. J Nat Prod 2009; 72:1825-1835. doi: http://dx.doi. org/10.1021/np9002977

106. Chithra S, Jasima B, Sachidanandan P, Radhakrishnana M, Jyothis EK. Piperine production by endophytic fungus Colletotrichum gloeosporioides isolated from Piper nigrum. Phytomedicine 2014; 21(4):534-540. doi: http://dx.doi. org/10.1016/j.phymed.2013.10.020

107. Qiu M, Xie RS, Shui Y, Zhang HH, Chen HM. Isolation and identification of two producing endophytic fungi from Ginkgo biloba L. Ann Microbiol 2010; 60:143-150.

108. Cui Y, Yi D, Bai X, Sun B, Zhao Y, Zhang Y. Ginkgolide B produced endophytic fungus (Fusarium oxysporum) isolated from Ginkgo biloba. Fitoterapia 2012; 83 (5):913-20. doi: http://dx.doi.org/10.1016/j.fitote.2012.04.009

\title{
Występowanie patogenicznych i endofitycznych grzybów i ich wpływ na jakość roślin zielarskich stosowanych w leczeniu chorób neurologicznych i psychicznych
}

\author{
KATARZYNA WIELGUSZ ${ }^{1}$, LIDIA IRZYKOWSKA ${ }^{2 *}$
}

\author{
${ }^{1}$ Instytut Włókien Naturalnych i Roślin Zielarskich \\ Zakład Hodowli i Agrotechniki Roślin Włóknistych i Energetycznych \\ ul. Wojska Polskiego $71 \mathrm{~b}$ \\ 60-630 Poznań
}


${ }^{2}$ Uniwersytet Przyrodniczy w Poznaniu

Katedra Fitopatologii i Nasiennictwa

ul. Dąbrowskiego 159

60-594 Poznań

*autor, do którego należy kierować korespondencję: tel: 4861848 79 27, faks: 486184879 99,

e-mail:irzyk@up.poznan.pl

\section{Streszczenie}

Ze względu na stały wzrost zapotrzebowania na jakość i bezpieczeństwo roślin zielarskich, należałoby zwrócić większą uwagę na ich zdrowotność. Wśród patogenów roślin zielarskich, szczególnie grzyby powodują poważne choroby, zmniejszając plon i jakość surowców roślinnych. Niektóre gatunki m.in. Fusarium sp., Alternaria sp., Penicillium sp. znane są jako producenci toksycznych metabolitów. Paradoksalnie ludzie próbujący leczyć się samodzielnie (używając surowców zielarskich), mogą być narażeni na działanie tych mykotoksyn. W tkankach niektórych roślin zielarskich występują (bezobjawowo) pozostałości grzybów endofitycznych. Wiadomo, że mają one zdolność wywierania wpływu na biosyntezę wtórnych metabolitów rośliny żywicielskiej lub wytwarzają związki biologicznie czynne. Do niedawna te mikroorganizmy były przeoczane jako „składnik” roślin zielarskich, co spowodowało, że nadal są polem niezbadanej bioaktywności i bioróżnorodności. W artykule przedstawiono przegląd roślin zielarskich stosowanych w leczeniu chorób układu nerwowego. Opisano grzyby patogeniczne dla tych roślin. Skupiono się głównie na gatunkach biosyntetyzujących szkodliwe mykotoksyny. Publikacja obejmuje listę tych mykotoksyn oraz krótki opis ich wpływu na zdrowie człowieka. Druga część artykułu dostarcza informacji o występowaniu grzybów endofitycznych w roślinach zielarskich i wpływie endofitów na zdrowie człowieka. Współistnienie grzybów i roślin leczniczych nie jest w pełni zrozumiane, a może być bardzo istotne dla zapewnienia zdrowia i bezpieczeństwa pacjentów z zaburzeniami neurologicznymi i psychicznymi.

Słowa kluczowe: leki ziołowe, fitoterapia, choroby roślin zielarskich, grzyby patogeniczne dla roślin, mykotoksyny, endofity, zaburzenia psychiczne, zaburzenia neurologiczne 